Egypt. J. of Appl. Sci., 36 (3) 2021

\title{
GENETIC VARIABILITY AND HERITABILITY IN SNAKE CUCUMBER
}

\author{
Abd Rabou, A. M. ${ }^{1}$; M.M. Ramadan ${ }^{2}$ and M. Abdel-Fatah ${ }^{3}$ \\ 1- Vegetables, Medicinal and Aromatic Plant Breeding Department, Hort. Res. Inst, \\ Agricultural Research Center (ARC), Giza, Egypt. \\ 2- Pests and Plant Protection Department, National Research Center(NRC) Giza, \\ Egypt.. \\ 3- Vegetables Department, Agricultural Fac., Cairo Unv., Giza, Egypt. \\ Corresponding author: aymanabdrabou40@gmail.com
}

Key Words: Genetic Variability, Heritability, Snake cucumber.

\section{ABSTRACT}

This study was conducted at Kaha Vegetable Research Farm (K.V.R.F), Qalubia governorate during the period from 2015 to 2017 to determine the genetic variability, and heritability among some snake cucumber inbred lines. The treatments consist of fifteen snake cucumber inbred lines, laid out in randomized complete block design (RCBD) and replicated three times. Inbred lines were evaluated for nine characters to determine variability and estimate heritability. Analysis of variance revealed highly significant $(\mathrm{P}<0.05)$ for all studied characters. L17, L12, L19, L20, L23, L24 and L27 were high resistant and resistant for powdery mildew. The results indicated the presence of substantial variability among the inbred lines. Genotypic coefficient of variation $(\mathrm{GCV})$, phenotypic coefficient of variation (PCV) and broad Sense heritability $\left(\mathrm{h}^{2}\right)$ estimates ranges from to $8.65 \%-74.24 \%, 9.03 \%-76.84 \%$ and 84.33 to $98.96 \%$ respectively. The high estimates of GCV and PCV in number of fruit plant (64.62 and 68.16 $\%$ respectively), sex ratio (74.24 and $76.84 \%$ respectively), and total yield plant (64.00 and $69.69 \%$ respectively) indicated the existence of variability and selection can be done. Whereas high estimate of $h^{2}$ for all the tested traits indicated that these characters were highly heritable and selection can be imposed. L19 and L24 were resistance for powdery mildew and had best marketable yield and fruit quality. Therefore, it is recommended for an effective selection of those characters which could be adopted for cultivar improvement program and more research is needed to validate the findings.

\section{INTRODUCTION}

Snake cucumber (Cucumis melo L. var. flexuosus) belongs to the family Cucurbitaceae. It is a type of long, slender fruit which tastes like a cucumber and looks somewhat like a cucumber inside and used when immature as an alternative to cucumber (Nuñez et al. 2008). It is an important crop, especially in the Middle East and North Africa. It is also known as Chinese, Oriental, Armenian, serpent cucumber (Splittstoesser 1990) or snake melon. It is actually a variety of muskmelon (C. melo), a species closely related to the cucumber ( $C$. sativus). The skin is very thin 
and bumpless. It has no bitterness and the fruit is almost always used without peeling (Abdel-Ghani and Mahadeen 2014).

Powdery mildew is a Very dangerous disease which reduces the yields of melon and other cucurbits, worldwide. Infection by powdery mildew is greatly influenced by the plant stage, humidity of air and temperature (Floris and Alvarez 1991). Singh (1987) reported that the fungi can sporulate and cause infection in very dry as well as wet atmosphere. Inbred lines with useful genes and quantitative resistance to powdery mildew, independent of environment are of prime importance. Genetic control of resistance/tolerance to powdery mildew has been investigated using progeny resulting from crosses between susceptible and resistant/tolerant genotypes (Kenigsbuch and Cohen1989). There is a high variability among snake cucumber landraces for morphological characters, yield and fruit attributes (Abd El-Salam et al. 2010 and Mohamed $\boldsymbol{e t}$ al. 2015). Snake cucumber plants have an outcrossing habit, so in this case landraces and local cultivars are populations of random mating individuals (Youssef 2018). Genetic variability studies provide the essential information about the genetic components of the population. The progress in snake cucumber breeding depends mainly on the magnitude of genetic variability present in the population and it is necessary to evaluate the genetic parameters such as genetic coefficient of variation, heritability and genetic advance (Abd El-Salam et al. 2010) Selection is the most efficient method for traits with high heritability. The information on heritability in conjunction with genetic advance are reliable estimations to identify characters for enforcing selection (Johnson et al. 1955). Heritability provides information on the magnitude of the inheritance of characters from parent to offspring, while genetic advance shows the degree of gain obtained in a character under a particular selection pressure (Nwangburuka $\boldsymbol{e t}$ al, 2012 and Ogunniyan et al. 2015)

The high heritability associated with high genetic advance for quantitative traits offer a better scope of selection of genotypes in early segregating generations. Broad sense heritability magnitudes in snake cucumber were high for number of fruits plant-1, yield plant-1, fruit length and fruit shape index (Abd El-Salam et al. 2010), so phenotypic selection for these traits would be reasonably effective. Moreover, it has been reported the association of number primary branches with stem length; fruit length with stem length; stem pubescence with both groove width and number of female to male flowers ratio; and fruit thickness with fruit length and fruit color with stem pubescence; that can be used in selection (Mohamed $\boldsymbol{e t} \boldsymbol{a l}$. 2010).

Estimates of phenotypic variance ( $\sigma 2 \mathrm{ph})$ were larger than the corresponding genotypic variance $(62 \mathrm{~g})$ for all examined traits. Moreover, close estimates of phenotypic coefficient of variation (PCV) and genotypic 
coefficient of variation (GCV) were noted in all characters, which imply the contribution to phenotypic expression of these characters are mostly due to genetic factors, while the environmental ones were not great importance (Youssef 2018). Although genotypic coefficient of variation revealed the extent of genetic variability present in the genotypes for various traits, it does not provide full scope to assess the heritable variation. Burton (1952) suggested that GCV together with heritability estimates would give the best insight into the extent of the advance to be expected by selection.

Heritability help in determining the influence of environment in expression of the characters and the extent to which improvement is possible after selection (Yadav et al. 2012). Abd El-Salam et al. (2009) indicated that broad sense heritability in snake cucumber was high for number of fruits/plant, yield/plant, and fruit length, but it was moderate for fruit diameter.

Despite the large variation that has been observed among snake cucumber cultivars, the efforts for development of new and superior varieties are still limited. Substantial effort has to be directed towards genetic breeding of existing cultivars (Youssef 2018). Hence, the objectives of this study are the genetic improvement of some snake cucumber inbred lines and study the genetic behavior of some economic traits.

\section{MATERIALS AND METHODS}

This study was conducted in Kaha Vegetable Research Farm (K.V.R.F), Qalubia governorate, Egypt during the period from 2016 to 2017. Fifteen inbred lines of snake cucumber (Cucumis melo L., var. flexuosus) were collected from Veget. Breed. Dep. of Hort. Res. Inst., gene bank of Sweden, gene bank of Netherland and open pollinate varieties from Pakistan (Table 1). All inbred lines were selfed for five generations to ensure homozygosity.

Table 1. Sources and performance of snake cucumber accessions used in the current study.

\begin{tabular}{|c|c|c|c|c|}
\hline No. & Inbred lines & Bitterness & Color & Region \\
\hline 1 & L4 & ------- & Dark green & Veget. Bred. Dep. \\
\hline 2 & L12 & - ------ & White & Pakistan \\
\hline 3 & L14 & $* * * *$ & White & Pakistan \\
\hline 4 & L16 & ------: & Dark green & Veget. Bred. Dep. \\
\hline 5 & L17 & $* * *$ & Dark green & Gene bank of Sweden \\
\hline 6 & L18 & $* * *$ & Light green & Gene bank of Sweden \\
\hline 7 & L19 & ------- & Green & Gene bank of Sweden \\
\hline 8 & L20 & 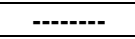 & White & Pakistan \\
\hline 9 & L21 & 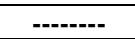 & Light green & Veget. Bred. Dep. \\
\hline 10 & L22 & ------: & White & Pakistan \\
\hline 11 & $\mathbf{L 2 3}$ & $\begin{array}{l}-\cdots---\cdot \\
--\cdot\end{array}$ & Dark green & Gene bank of Netherland \\
\hline 12 & L24 & ------- & Dark green & Gene bank of Sweden \\
\hline 13 & L25 & ------- & White & Pakistan \\
\hline 14 & L26 & $* * *$ & Dark green & Gene bank of Netherland \\
\hline 15 & L27 & $* * *$ & Dark green & Gene bank of Netherland \\
\hline
\end{tabular}


The evaluation of resistance for the inbred lines to powdery mildew was carried in (K.V.R.F) during March 2015.

\section{Inoculation with pathogen:}

Plants of three leaves stage were inoculated with powdery mildew spores using the spray inoculation method in March 2015 The infected leaves as spores source were collected from infected melon plants, and spores were used to make a suspension solution with density of 20 spore/sight $(10 \times 10$ fold) as described by Tang et al (2003). Data were recorded after 6 weeks of inoculation with spore suspension of $E$. cichoracearum.

\section{Disease assessment:}

Infection on plants was measured 30 days after inoculation in the greenhouse. A linear 0-4 scale (Table 2) indicating average rating of all the leaves was used to assess the disease in experiment. On the basis of scoring of 3 individual leaves per plant and 10 plants in each inbred line, Percent Disease Index (PDI) was calculated for each inbred line using the formula proposed by Wheeler (1969):

$$
P D I=\frac{\text { Sum of numerical values }}{\text { No of lesaves } x \text { Maximum rating }} \times 100
$$

Seeds of 15 inbred lines were directly planted for horticultural evaluation in (K.V.R.F) on open field at 16th March, 2016 and 21th March 2017 In each trial a randomized complete block design (RCBD) was established for 15 treatments with 3 replicates, each replicate consisted of 15 plots each plot contained 10 plants represent the inbred lines. Plants were grown on ridges with dimensions of $40 \mathrm{~m}$ long and $1 \mathrm{~m}$ wide. The area of each plot was $2.5 \mathrm{~m} 2$; plants were grown at a distance of $50 \mathrm{~cm}$ apart on both sides of the ridge. All the agriculture practices were carried out according to the recommendation of Ministry of Agriculture, Egypt.

Table 2. Powdery mildew disease severity estimating into 5 categories according to James (1971).

\begin{tabular}{llll}
\hline Scale & Mildew covering of leaf surface & symptoms & Reaction \\
\hline $\mathbf{0}$ & $\mathbf{0 \%}$ & No symptoms of infection & High resistance (HR) \\
$\mathbf{1}$ & $\mathbf{1 - 1 2 . 5 \%}$ & Very weak infection & Resistance (R) \\
$\mathbf{2}$ & $\mathbf{1 3 - 2 5 \%}$ & Weak infection & Tolerance (T) \\
3 & $\mathbf{2 5 . 5 - 5 0 \%}$ & Moderate infection & Susceptible (S) \\
$\mathbf{4}$ & $\mathbf{5 0 . 5}-\mathbf{1 0 0 \%}$ & Very severe infection & High susceptible (HS) \\
\hline
\end{tabular}

Data were recorded on individual 10 plants of each inbred lines for main stem length $(\mathrm{cm})$, average fruit diameter $(\mathrm{cm})$, average fruit length $(\mathrm{cm})$, average fruit weight $(\mathrm{g})$, number of fruits/plant, sex ratio, earliness, and total yield/plant $(\mathrm{kg})$. 
Observations were recorded on various characters and subjected to statistical analysis. Collected data were subjected to analysis of variance (ANOVA) using Statistix 8 software version 8.0 (2003) and correlation was also determined. Genotypic coefficient of variation (GCV), phenotypic coefficient of variation (PCV), and environmental coefficient of variation (ECV) were calculated according to (Sivasubramanian and Menan 1973) and heritability (h2) was calculated according to Johnson et al (1955).

\section{RESULS AND DISCUTIONS}

Evaluation cucumber inbred lines for powdery mildew resistance:

Data obtained on the reaction of snake cucumber inbred lines evaluated for powdery mildew resistance under artificial infection conditions on green house in 2015 and presented in Table (3) and Fig.(1).

Among 15 inbred lines cultivated L17 showed completely free from infection, this is meaning it is high resistance based on the five categories according to (James 1971). L12, L19, L20, L23, L24 and L27 showed low infection (resistant) . On the other hand the other inbred lines varied between tolerant (L14 and L25), susceptible (L16 and L18) and four inbred lines showed highly infection, (L4, L21, L22 and L26) i.e. these inbred lines are highly susceptible to powdery mildew.

Table 3. Quantitative genetic parameters of powdery mildew in snake cucumber inbred lines.

\begin{tabular}{|c|c|c|}
\hline Inbred lines & Mildew \% & Reaction \\
\hline $\mathrm{L} 4$ & 61.4 & HS \\
\hline L12 & 3.3 & $\mathbf{R}$ \\
\hline L14 & 23.3 & $\mathbf{T}$ \\
\hline L16 & 38.2 & $\mathbf{S}$ \\
\hline L17 & 0.9 & HR \\
\hline L18 & 25.8 & $\mathbf{S}$ \\
\hline L19 & 2 & $\mathbf{R}$ \\
\hline L20 & 3.7 & $\mathbf{R}$ \\
\hline L21 & 87 & HS \\
\hline L22 & 78.4 & HS \\
\hline $\mathrm{L23}$ & 2.7 & $\mathbf{R}$ \\
\hline L24 & 3.7 & $\mathbf{R}$ \\
\hline L25 & 23.3 & $\mathbf{T}$ \\
\hline L26 & 93 & HS \\
\hline L27 & 6.6 & $\mathbf{R}$ \\
\hline LSD & 2.7 & \\
\hline
\end{tabular}




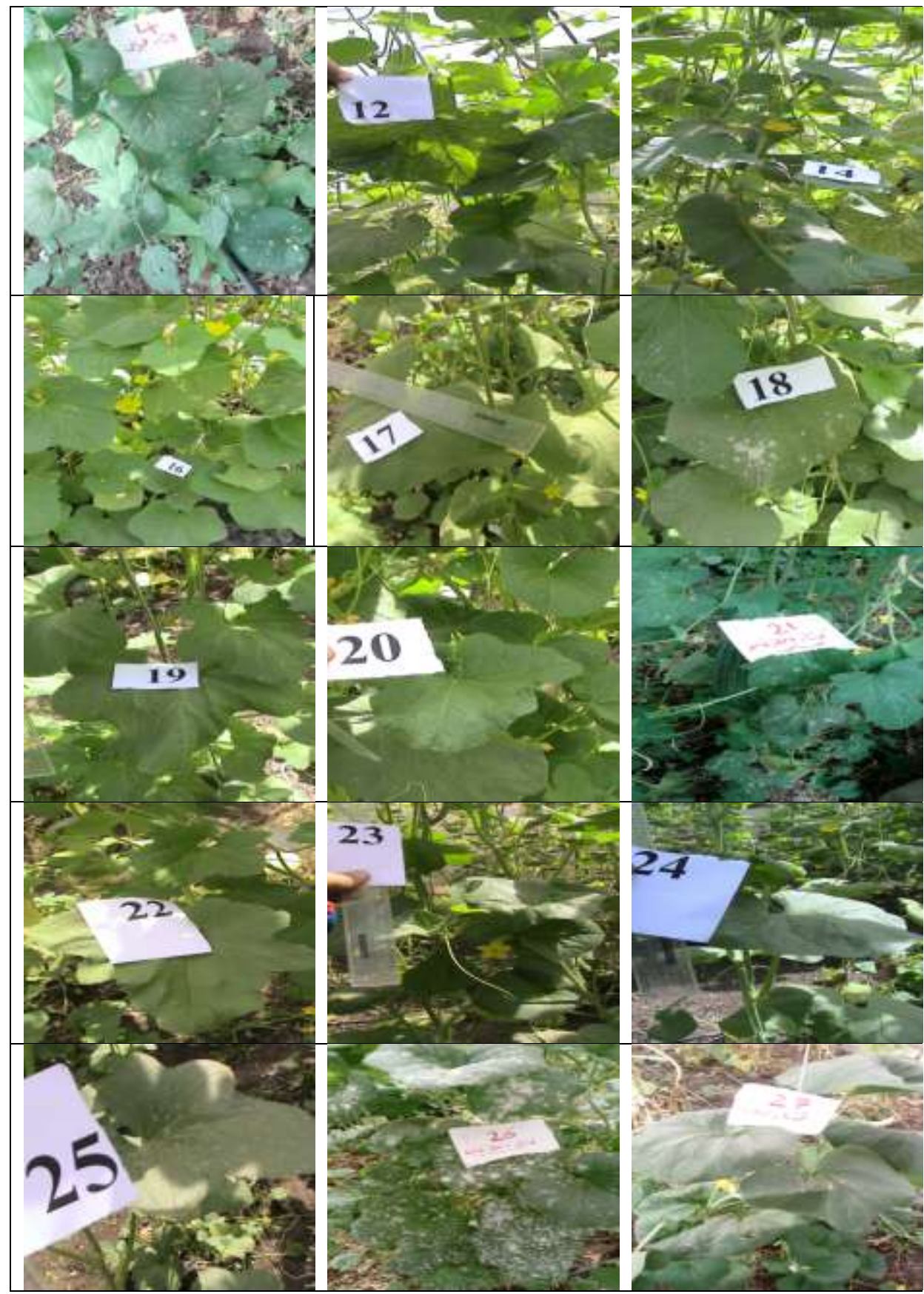

Fig. 1: powdery mildew resistance and Fruit quality differences of the parental melon genotypes. 


\section{Mean performance:}

Means of 8 horticultural traits for 15 snake cucumber inbred lines in Tables (4 and 5). Differences among inbred lines for all studied characters were significant, indicating wide diversity among these inbred lines

\section{1- Main stem length}

Data showed that inbred lines L12 and L22 had the highest values of main stem length in both two seasons (269.2, 272.0, 269.9 and 272.7 $\mathrm{cm}$, respectively), with significant differences with the other inbred lines in 2016 and 2017. The L4 was lowest of main stem length the two seasons $(184.5$ and $187.3 \mathrm{~cm})$ with significant differences with the other inbred lines.

Table 4. Means performance of studied snake cucumber inbred lines.

\begin{tabular}{|c|c|c|c|c|c|c|c|c|}
\hline \multirow{2}{*}{$\begin{array}{c}\text { Inbred } \\
\text { lines }\end{array}$} & \multicolumn{2}{|c|}{ Main stem length $(\mathrm{cm})$} & \multicolumn{2}{|c|}{$\begin{array}{l}\text { Average fruit } \\
\text { diameter }(\mathrm{cm})\end{array}$} & \multicolumn{2}{|c|}{$\begin{array}{l}\text { Average fruit length } \\
\text { (cm) }\end{array}$} & \multicolumn{2}{|c|}{$\begin{array}{l}\text { Average fruit } \\
\text { weight (g) }\end{array}$} \\
\hline & 2016 & 2017 & 2016 & 2017 & 2016 & 2017 & 2016 & 2017 \\
\hline L4 & 184.5 & 187.3 & $* * 6.77$ & $* * 7.57$ & 21.4 & 22.2 & 130.4 & 133.2 \\
\hline L12 & $* * 269.2$ & $* * 272.0$ & 4.53 & 5.13 & 51.2 & 51.8 & 182.9 & 184.5 \\
\hline L14 & 252.9 & 255.7 & 4.53 & 4.93 & $* * 73.4$ & $* * 73.8$ & $* * 376.4$ & $* * 379.0$ \\
\hline L16 & 240.8 & 243.6 & 4.57 & 5.37 & 61.7 & 62.5 & 324.5 & 326.1 \\
\hline L17 & 214.4 & 217.2 & 4.70 & 5.10 & 42.2 & 42.6 & 231.0 & 232.6 \\
\hline L18 & 253.6 & 256.4 & 5.10 & 5.70 & $* * 73.2$ & $* * 73.8$ & 318.2 & 321.0 \\
\hline L19 & 248.8 & 251.6 & 4.93 & 5.73 & 67.5 & 68.3 & 271.1 & 272.7 \\
\hline L20 & 237.0 & 239.8 & 4.60 & 5.00 & $\begin{array}{ll}64.8 \\
\end{array}$ & 65.2 & 298.1 & 299.7 \\
\hline L21 & 231.7 & 234.5 & 5.63 & 6.43 & 34.9 & 35.7 & 207.5 & 210.3 \\
\hline L22 & $* * 269.9$ & $* * 272.7$ & 4.50 & 5.10 & $* * 76.8$ & $* * 77.4$ & \begin{tabular}{|l|}
308.1 \\
\end{tabular} & \begin{tabular}{|c|}
315.9 \\
\end{tabular} \\
\hline L23 & 228.4 & 231.2 & 5.37 & 5.77 & 35.9 & 36.3 & 171.0 & \begin{tabular}{|l|l|}
173.8 \\
\end{tabular} \\
\hline L24 & 236.1 & 238.9 & 4.43 & 5.23 & 61.4 & 62.2 & 237.4 & \begin{tabular}{|l|}
239.0 \\
\end{tabular} \\
\hline L25 & 232.9 & 235.7 & 6.17 & 6.57 & 41.4 & 41.8 & 249.5 & 251.1 \\
\hline L26 & 217.1 & 219.9 & 4.43 & 5.03 & 64.2 & \begin{tabular}{|l|l|}
64.8 \\
\end{tabular} & \begin{tabular}{|l|l|}
300.4 \\
\end{tabular} & \begin{tabular}{|l|}
303.2 \\
\end{tabular} \\
\hline L27 & 225.0 & 227.8 & 4.17 & 4.57 & 48.8 & 49.23 & 183.0 & 184.6 \\
\hline Lsd & $\begin{array}{l}9.5 \\
\end{array}$ & \begin{tabular}{|l|l|}
10.3 \\
\end{tabular} & 0.40 & 0.60 & 4.9 & 5.32 & 28.3 & 28.9 \\
\hline
\end{tabular}

These results agreement with (Youssef 2018) who evaluated three local cultivars of snake cucumber and their generations and found values of main stem length ranged from 167.12 to $272.31 \mathrm{~cm}$.

\section{2- Fruit diameter:}

Data obtained on the trait fruit diameter of 15 snake cucumber inbred lines are presented in table (4). Data showed that only L4 gave the highest values of fruit diameter in both seasons $(6.77$ and $7.57 \mathrm{~cm}$, respectively), with significant differences with the other inbred lines in 2016 and 2017. The lowest fruit diameter was obtained on L27 (4.17 and $4.57 \mathrm{~cm}$ ) in both seasons, respectively. Youssef (2018) reported in his studied on snake cucumber that values of fruit diameter ranged from 3.13 to $4.53 \mathrm{~cm}$.

\section{3- Fruit length:}

Data obtained on the trait fruit length are illustrated in table (4) The results obtained that the 3 inbred lines (L14, L18 and L22) gave fruit 
length above $70 \mathrm{~cm}$ in both two seasons. On the contrary, L4 gave the shortest fruit length on both season $(21.4$ and $22.2 \mathrm{~cm}$, respectively).Youssef (2018) reported in his studied on snake cucumber that values of fruit diameter ranged from 28.53 to $36.84 \mathrm{~cm}$.

\section{4- Fruit weight:}

Data obtained on fruit weight are illustrated in table (4). L14, L18 and L22 gave fruit weight above $300 \mathrm{~g}$ in both two seasons, but L14 gave the heaviest fruit weight in both two seasons (376.4 and $379.0 \mathrm{~g}$, respectively). The lightest fruit weight was obtained in inbred line L4 (130.4 and $133.2 \mathrm{~g}$ ) in both seasons respectively. it could be concluded that inbred lines L14, L18 and L22 had the highest value of fruit length, diameter and weight.

\section{5- Number of fruits per fruit}

Number of fruits per plant of the studied inbred lines had wide range from 4.7 to 15.80 fruits (Table 5) in both seasons. The inbred lines L19, L23 and L37 had the highest number of fruits per plant with significant differences with the other inbred lines in 2016 and 2017. on the other hand, L12, L18, L22 and L26 had the lowest number of fruits per plant with significant differences with the other inbred lines in 2016 and 2017.

Table 5. Means performance of studied snake cucumber inbred lines.

\begin{tabular}{|c|c|c|c|c|c|c|c|c|}
\hline \multirow{2}{*}{ Inbred lines } & \multicolumn{2}{|c|}{ No. fruits/plant } & \multicolumn{2}{|c|}{ Sex ratio } & \multicolumn{2}{|c|}{ Earliness } & \multicolumn{2}{|c|}{ Total yield (kg/plant) } \\
\hline & 2016 & 2017 & 2016 & 2017 & 2016 & 2017 & 2016 & 2017 \\
\hline L4 & 11.4 & 12.23 & $* * 0.103$ & $* * 0.108$ & $* * 56.8$ & $* * 59.6$ & 1.50 & 1.63 \\
\hline $\mathbf{L 1 2}$ & 4.7 & 5.27 & 0.020 & 0.025 & 46.6 & 48.2 & 0.90 & 0.97 \\
\hline L14 & 8.2 & 8.63 & 0.050 & 0.054 & 52.1 & 54.7 & $* * 3.13$ & $* * 3.27$ \\
\hline L16 & 10.6 & 11.37 & 0.060 & 0.066 & 48.7 & 50.3 & $* * 3.37$ & $* * 3.71$ \\
\hline L17 & 11.6 & 11.97 & 0.057 & 0.061 & 52.8 & 54.4 & 2.67 & 2.78 \\
\hline L18 & 4.8 & 5.40 & 0.040 & 0.043 & 51.9 & 54.7 & 1.53 & 1.73 \\
\hline L19 & $* * 15.0$ & $* * 15.80$ & 0.057 & 0.062 & 49.1 & 50.7 & $* * 4.07$ & $* * 4.31$ \\
\hline L20 & 7.8 & 8.23 & $\mathbf{0 . 0 3 3}$ & 0.039 & 51.7 & 53.3 & 2.30 & 2.47 \\
\hline L21 & 11.8 & 12.60 & 0.060 & 0.061 & 50.2 & 53.0 & 2.47 & 2.65 \\
\hline L22 & 4.9 & 5.50 & 0.027 & 0.031 & 50.0 & 52.8 & 1.37 & 1.54 \\
\hline $\mathbf{L 2 3}$ & $* * 13.0$ & $* * 13.40$ & 0.073 & 0.078 & 49.2 & 52.0 & 2.20 & 2.33 \\
\hline L24 & 5.0 & 5.80 & 0.027 & 0.033 & 46.9 & 48.5 & 1.20 & 1.39 \\
\hline L25 & 9.9 & 10.30 & 0.030 & 0.034 & 49.6 & 51.2 & 2.47 & 2.59 \\
\hline L26 & 4.9 & 5.47 & 0.047 & 0.055 & 49.5 & 52.3 & 1.47 & 1.66 \\
\hline L27 & $* * 13.0$ & $* * 13.40$ & 0.073 & 0.078 & 47.4 & 49.0 & 2.37 & 2.47 \\
\hline Lsd & 2.3 & 2.60 & 0.009 & 0.012 & 2.2 & 2.8 & 1.02 & 1.07 \\
\hline
\end{tabular}

\section{6- Sex ratio:}

Sex ratio ranged from 0.020 to 0.108 in both seasons. L4 gave the highest value of sex ratio (0.103 and 0.108$)$ in both seasons respectively. L12, L22 and L27 gave the lowest value of sex ratio (ranged between 
0.20 to 0.033 ) in both seasons respectively, with significant differences with other inbred lines.

\section{7- Earliness:}

Earliness in the studied 15 snake cucumber inbred lines ranged from 46.6 to 59.6 days (Table 5) in the two seasons of 2016 and 2017. Earliness was clear in L12 (46.6and 48.2 days), L16 (48.7 and 50.3 days), L24 (46.9 and 48.5 days) and L27 (47.4 and 49.0 days) in both seasons of study. L4 was the Latest value obtained with L4 in both seasons (56.8 and 59.6 days).

\section{8- Total yield/plant:}

Data obtained on the total yield per plant are illustrated in table (5). The results indicated that evaluation of inbred lines based on higher yield per plant ranged from $(0.90$ to $4.07 \mathrm{~kg})$ and $(0.97$ to $4.31 \mathrm{Kg})$ in both seasons respectively, L19 $(4.07$ and $4.31 \mathrm{Kg})$ as the top ranking inbred line without significant differences with L14 in both seasons. L12 had the lowest values of total yield per plant in two season. Youssef (2018) reported in his studied on snake cucumber that values of Total yield/plant ranged from 4.40 to $7.51 \mathrm{~kg}$.

\section{Genetic studies}

Improvement of snake cucumber depends on the nature and magnitude of genetic variability in the population. Genetic variability studies provide basic information regarding the genetic properties of the population. The extent of variability presented in snake cucumber cultivars was measured in terms of phenotypic variance ( $\sigma 2 \mathrm{ph})$, genotypic variance $(\sigma 2 \mathrm{~g})$, phenotypic coefficient of variation (PCV), genotypic coefficient of variation $(\mathrm{GCV})$ and heritability $(\mathrm{h} 2 \mathrm{~b})$ as shown in Table 6.

\section{- PCV and GCV}

Estimates of phenotypic variance (VP) were larger than the corresponding genotypic variance (VG) for all examined traits. Moreover, close estimates of phenotypic coefficient of variation (PCV) and genotypic coefficient of variation (GCV) were noted in all characters, which imply the contribution to phenotypic expression of these characters are mostly due to genetic factors, while the environmental ones were not great importance. Characters having a high genotypic coefficient of variation indicate a high potential for effective selection. These findings are in agreement with those reported by Rakhi and Rajamony (2005), Mehta et al. (2009), Ibrahim (2012), Potekar et al. (2014) and Janghel et al. (2018). 
Greater variability ensures better changes of producing new desirable forms. Genotypic coefficient of variation (GCV) and phenotypic coefficient of variation (PCV) were computed for nine studied characters on 15 snake cucumber inbred lines (Table 6). The GCV ranged from $8.65 \%$ (earliness) to $74.24 \%$ (sex ratio). The PCV for different characters ranged from $9.03 \%$ (earliness) to $76.84 \%$ (sex ratio).High amount of fixable variation in watermelon characters has been reported by (Youssef 2018). In the present study, high estimates of both GCV and PCV were registered for the studied traits, viz., NF (64.62 and $68.16 \%$ respectively), SX (74.24 and $76.84 \%$ respectively), and TY (64.00 and $69.69 \%$ respectively) which suggest greater phenotypic and genotypic variability among the accession and responsiveness of the attributes for making further improvement by selection.

Moderate estimates of GCV and PCV were registered for the traits Fruit length (52.42 and $52.69 \%$ respectively) and fruit weight (46.28 and $46.78 \%$ respectively).

Low estimates of GCV and PCV were registered for the traits viz., stem length (15.90 and $16.08 \%$ respectively), Fruit diameter (25.05 and $25.50 \%$ respectively) and earliness yield per plant (8.65and $9.03 \%$ respectively), which indicated that these traits were less affected by environment. Indiresh (1982) reported similar results in bitter gourd. This suggests that these characters may be less influenced by environment which is agreement with the findings of (Tomer et al. 2008) in muskmelon.

\section{- Heritability}

In the present study, almost all the characters exhibited high heritability value which ranged from 84.33 to $98.96 \%$ table (7). High heritability values obtained for all traits in the present study suggest that these traits may generally be governed by additive gene action and hence the phenotype would provide a fairly reliable measure of the inbred line which provides scope for selection based on the phenotypic performance

In general, we can notice that the differences between phenotypic and genotypic variance for all studied traits were low. In other words, the large portion of phenotypic variance $(\mathrm{Vp})$ was due to the genetic variance $(\mathrm{Vg})$. Consequently, estimated broad-sense heritability showed high values for these traits, indicating that the observed significant phenotypic differences among the studied inbred lines are of genetic nature and there are small environmental effects on the phenotypic variation. Therefore, 
these characters can be improved through selection based on phenotypic observations in early segregating generations in watermelon germplasm.

Table 7. Estimation of PCV, GCV, heritability and genetic advance as per cent of mean for various characters in snake cucumber.

\begin{tabular}{|c|c|c|c|c|c|c|c|}
\hline No. & Characters & $\mathbf{V}_{\mathbf{E}}$ & $\mathbf{V}_{\mathbf{G}}$ & $\mathbf{V}_{\mathbf{P}}$ & GCV\% & PCV\% & $h^{2}(\%)$ \\
\hline 1 & SL & 32.17 & 1409.14 & 1441.31 & 15.90 & 16.08 & 97.77 \\
\hline 2 & FD & 0.06 & 1.54 & 1.60 & 25.05 & 25.50 & 96.51 \\
\hline 3 & FL & 8.64 & 819.05 & 827.69 & 52.42 & 52.69 & 98.96 \\
\hline 4 & FW & 287.30 & 13455.80 & 13743.10 & 46.28 & 46.78 & 93.33 \\
\hline 5 & NF & 3.90 & 34.61 & 38.51 & 64.62 & 68.16 & 89.87 \\
\hline 6 & SX & 0.0001 & 0.0014 & 0.0015 & 74.24 & 76.84 & 93.33 \\
\hline 7 & EA & 1.70 & 18.83 & 20.53 & 8.65 & 9.03 & 91.73 \\
\hline 8 & TY & 0.37 & 1.98 & 2.35 & 64.00 & 69.69 & 84.33 \\
\hline \multicolumn{8}{|c|}{ 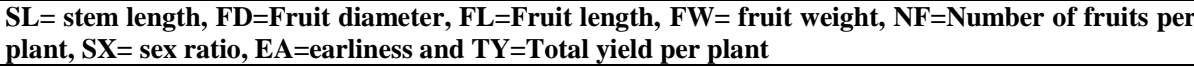 } \\
\hline
\end{tabular}

\section{CONCLUSION}

Results showed that L19 ( resistant, no bitterness, high number fruit per plant, high total yield and marketable fruit characters ) and L24 ( resistant, no bitterness, earliness and marketable fruit characters) were the best inbred lines which can suggested to be introduction in breeding programmer to produce new variety.

\section{REFERENCES}

AbdEl-Salam, M.M.M. ; I.S. El-Demrdash and A.H. Hussein (2009). Phenotypic stability analysis, heritability and protein patterns of snake cucumber genotypes. $6^{\text {th }}$ International Plant Breeding Conference, Ismailia, Egypt, 3-5 May, 791-798.

AbdEl-Salam, M.M.M. ; I.S. El-Demardash and A.H. Hussein (2010). Phenotypic stability analysis, heritability and protein patterns of snake cucumber genotypes. J. of American Sci; 6(12):503-507.

Abdel-Ghani, A.H. and A. Mahadeen (2014). genetic variation in snake melon (Cucumis melo var. flexuosus) populations from Jordan using morphological traits and RAPDs. Jordan Journal of Agricultural Sciences, 10(1):96-119.

Burton, G.W.(1952). Quantitative inheritance in grasses. Proc. Sixth Int. Grassland Congr. 1:277-283.

Floris, E. and J. M. Alvarez (1991). Inheritance of resistance to phaerotheca fuliginea in two local melon cultivars. Acta Hort., 488: 119-124. 
Ibrahim, E.A. (2012). Variability, heritability and genetic advance in Egyptian sweet melon (Cucumis melo var. aegyptiacus L.) under water stress conditions. International J. of Plant Breed and Genet. 6:238-244.

Indiresh, B. T. (1982). Studies on Genotypic Variability in Bitter Gourd (Momordicacharantia L.) M.Sc. (Agri.) Thesis abstr. 8 (1): Univ. Agri. Sci. Bangalore.

James, W.C. (1971). A mannual of assessment keys for plant disease. Canada Dep. Agric. Publication No. 1458.

Janghel A.K. , J. Trivedi, D. Sharma, Y. Lodhi and L. Kand Kumar. (2018). Genetic variability in muskmelon (Cucumis melo L.) Under Protected Condition. Int. J. Curr. Microbiol. App. Sci., 6: 211-217.

Johnson, H.W. ; H.F. Robinson and R.E. Comstock (1955) Estimates of genetic and environmental variability in soybeans. Agron. J; 47:314-318.

Kenigsbuch, D. and Y. Cohen (1989). Independent inheritance of resistance to race 1 and 2 of Sphaerotheca fuliginea in muskmelon. Plant Dis., 73: 206-208.

Mehta, R. ; D. Singh and M.K. Bhalala (2009). Genetic variability, heritability and genetic advance in muskmelon (Cucumis melo L.). Veg. Sci., 36:248-250.

Mohamed, T.Y. ; T.M. Elamin ; A.M. Baraka ; A.A. El Jack and E.A. Ahmed (2010) Variability and Correlation among morphological, vegetative, fruit and yield parameters of snake melon (Cucumis melo Var.flexuosus). Cucurbit Genetics Cooperative Report. 2010-2011;33-34: 32-35.

Mohammed, S.A. ; R.M. Jamous ; M.J. Shtaya ; O.B. Mallah ; I.S. Eid and S.Y. AbuZaitoun (2015). Morphological characterization of snake melon (Cucumis melo var. flexuosus) populations from Palestine. Genet Resour Crop Evol.; 64:7-22.

Nuñez, P. ; G. Hector ; L. Gomez ; O. A. Miguel ; G. Neftali ; L. G. Rebecca and D. J. Cantliffe (2008). Melon fruits: genetic diversity, physiology, and biotechnology features. Critical Reviews in Biotechnology, 28 (1): 13-55.

Nwangburuka, C.C. and O.A. Denton (2012) Heritability, character association and genetic advance in six agronomic and yield related characters in leaf Corchorus olitorius. Int. J. Agric. Res., 7:367-375. 
Ogunniyan, D.J. and S.A. Olakojo (2015) Genetic variation, heritability, genetic advance and agronomic character association of yellow elite inbred lines of maize (Zea mays L.). Niger. J. Genet., 28: 24-28.

Potekar, S.V. ; P.K. Nagre and S.N. Sawant(2014). Genetic variability study in muskmelon (Cucumis melo L.). International J. Tropic. Agric.,32(3-4):349-351.

Rakhi, R. and L. Rajamony (2005). Variability, heritability and genetic advance in landraces of culinary melon (Cucumis melo L.). J. of Tropical Agriculture. 43(1-2): 79-82.

Singh, R.S. (1987): Diseases of Vegetable Crops. Oxford and IBH Publication, New Delhi, India.

Sivasubramanian, S. and M. Menan (1973). Heterosis and inbreeding depression in rice. Madras Agric. J., 60: 1139.

Splittstoesser, W.E. (1990) Vegetable growing handbook. Organic and traditional methods. 3id Ed. Chapman \& Hall, NY, USA.

Tang, R. ; X. Zhang ; T. Hu and K. Cao (2003). Control Effect of the Extracts from Rheum palmatum on Powdery Mildew of Cucumber. J. Anhui. Agric. Univ., 30(4): 363 - 366.

Tomer, R.S. ; G.U. Kulkarni ; D.K. Kakade ; A.D. Patel and R.R. Acharya (2008). Genetic variability, correlation and path analysis in musk melon (Cucumis melo L.). Asian J. Hort., 3 (1): 158-161.

Wheeler, B.E. (1969) An Introduction to Plant Diseases. John Wiley and Sons, London.

Yadav, Y.C. ; S. Kumar and R. Singh (2012). Studies on genetic variability, heritability and genetic advance in cucumber (Cucumis sativus L.). Hort. Flora Research Spectrum, 1(1): 34-37.

Youssef, M.M. (2018): Genetic Improvement of Yield and Fruit Traits in Snake Cucumber (Cucumis melo var. flexuosus L.) by Individual Selection. Asian Journal of Biotechnology and Genetic Engineering 1(2): 1-10, Article no.AJBGE.43185. 
طول الثمرة، متوسط وزن الثمرة، النسبة الجنسية ، التبكير ، عدد الثمار بالنبات والمحصول الكلى

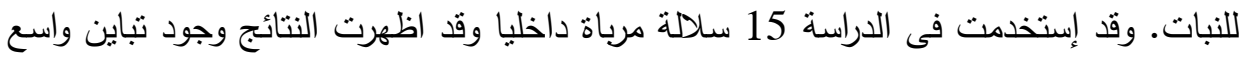
واختلافات معنوية عالية للصفات محل الدراسة. وتراوحت قيم كلا من معامل التباين الوراثي

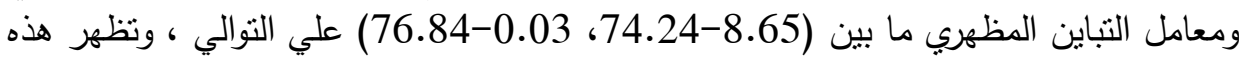

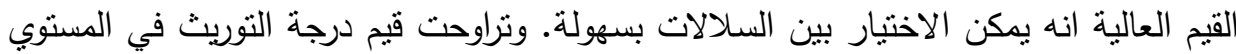

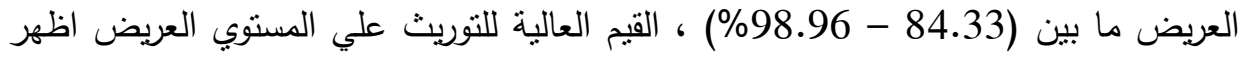
ان الصفات قابلة للتوريث بدرجة عالية وانه يمكن الاختيار فيما بينها بسهولة.

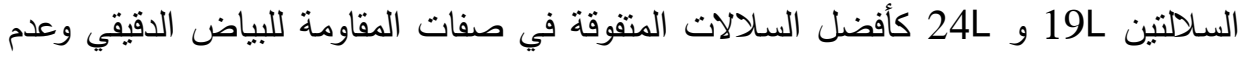

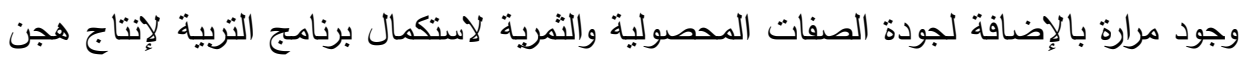

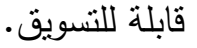

